\title{
RECYSTALLIZATION OF HSLA STEEL AUSTENITE AS REVEALED WITH A HOT-COMPRESSION TEST
}

\author{
REKRISTALIZACIJA AUSTENITNEGA HSLA JEKLA, DOLOČENA \\ Z VROČIM TLAČNIM PREIZKUSOM
}

\author{
Elżbieta Kalinowska-Ozgowicz' ${ }^{1}$, Roman Kuziak², Wojciech Ozgowicz ${ }^{3}$ \\ ${ }^{1}$ Lublin University of Technology, Fundamentals of Technology Faculty, 38 Nadbystrzycka Str., 20-618 Lublin, Poland \\ ${ }^{2}$ Institute for Ferrous Metallurgy, 12 K. Miarki Str., 44-100 Gliwice, Poland \\ ${ }^{3}$ Silesian University of Technology, Mechanical Engineering Faculty, Institute of Engineering Materials and Biomaterials, \\ 18A Konarskiego Str., 44-100 Gliwice, Poland \\ wojciech.ozgowicz@tlen.pl
}

Prejem rokopisa - received: 2017-05-30; sprejem za objavo - accepted for publication: 2017-10-02

doi:10.17222/mit.2017.065

\begin{abstract}
Hot deformation of the HSLA-type steel was investigated applying the method of the relaxation of stresses by means of a Gleeble 3800 thermomechanical simulator. The influence of the conditions of plastic deformation on the shape of stress-strain flow curves and the kinetics of thermally activated static processes were determined. It was found that the microstructure of the investigated steel and the state of the precipitations of $\mathrm{Nb}$ and $\mathrm{Ti}$ carbonitrides after hot deformation depend mainly on the degree of deformation and the time of the relaxation of stresses.
\end{abstract}

Keywords: HSLA steel, hot compression test, stress relaxation method, softening kinetics, microstructure

Avtorji v članku opisujejo raziskavo vroče deformacije malo legiranega jekla z veliko trdnostjo process (HSLA, angl.: High Strength Low Alloyed) z uporabo metode sprostitve napetosti na termomehanskem simulatorju Gleeble 3800. Določili so vpliv plastične deformacije na obliko krivulj tečenja napetost-deformacija in kinetiko termično aktiviranih procesov. Ugotovili so, da sta mikrostruktura preiskovanega jekla ter izločanje $\mathrm{Nb}$ in Ti karbonitridov po vroči deformaciji, $\mathrm{v}$ glavnem odvisna od stopnje deformacije in casa potrebnega za sprostitev napetosti.

Ključne besede: malolegirano jeklo z veliko trdnostjo (HSLA), vroči tlačni preizkus, metoda sprostitve napetosti, kinetika mehčanja, mikrostruktura

\section{INTRODUCTION}

High-strength low-alloy (HSLA) steels are already well established in the fields of numerous technical applications due to the possibility of reducing the masses of structures and an improvement in the strength of steel products. The attainment of favorable mechanical and exploitable properties of this group of material depends particularly on the proper hot deformation, recrystallization and final cooling of the products. ${ }^{1-4}$ This process results in the creation of adequate mechanisms of strain hardening and recrystallization of steel ensuring the required properties of the products at the stage of their exploitation. ${ }^{5-7}$ The mechanisms of hot deformation and recrystallization are mostly analyzed based on the shape of the stress-strain $(\sigma-\varepsilon)$ flow curves and the kinetic curve of the recrystallized fraction in the function of the time of isothermal holding or cooling after the deformation. These curves are usually determined with various kinds of mechanical tests supported by a metallographic investigation. ${ }^{8-12}$
The aim of the researches of the microalloyed $\mathrm{C}-\mathrm{Mn}-\mathrm{Nb}$ steel was to determine the influence of the parameters of the hot-compression tests of axially symmetric samples on the process of strain hardening and dynamic recrystallization and on the static kinetics of thermally activated processes occurring isothermally after the deformation. The method of the relaxation of stresses was used for this purpose, applying a computercontrolled Gleeble 3800 thermomechanical simulator.

\section{EXPERIMENTAL PART}

\subsection{Material and methods}

The tests were performed on an industrial melt of microalloyed C-Mn-Nb steel (grade S355NL, according to standard PN-EN10025-2:2007) of the HSLA type, the chemical composition of which is seen in Table 1.

The steel was delivered as a profile of the economical channel $240 \mathrm{E}$ in its raw state after hot rolling. Test samples were cut from the profile in the direction of

Table 1: Chemical composition of the tested steel, in mass fractions $(w / \%)$

\begin{tabular}{|c|c|c|c|c|c|c|c|c|c|c|c|c|}
\hline Steel & $\mathrm{C}$ & $\mathrm{Si}$ & $\mathrm{Mn}$ & $\mathrm{P}$ & $\mathrm{S}$ & $\mathrm{Cu}$ & $\mathrm{Al}$ & $\mathrm{N}$ & $\mathrm{Nb}$ & $\mathrm{V}$ & $\mathrm{Ti}$ & $\mathrm{Fe}$ \\
\hline $\mathrm{C}-\mathrm{Mn}-\mathrm{Nb}$ & 0.16 & 0.29 & 1.48 & 0.030 & 0.017 & 0.049 & 0.01 & 0.0098 & 0.037 & 0.002 & 0.004 & bal. \\
\hline
\end{tabular}


rolling. Plastometric tests applying the method of axially symmetric hot compression were carried out on the simulator Gleeble 3800, using cylindrical samples with a diameter of $7 \mathrm{~mm}$ and a length of $8.4 \mathrm{~mm}$. The samples were resistance heated in an $\mathrm{Ar}$ atmosphere. In order to reduce the friction on the surface, the samples were lubricated with graphite and interlayered with a foil of Ta. During the tests, the force was measured as a function of the anvil displacement, the temperature on the side surface of the samples, and the shape of the samples after upsetting. The drop in the compressive force was recorded as a function of time. The kinetics of the static softening after hot deformation was tested applying the method of stress relaxation in the case of logarithmic strain $\left(\varepsilon=\ln \left(h_{0} / h\right)\right.$ where $\mathrm{h}_{0}$ and $\mathrm{h}$ are the initial and final sample heights, respectively) within a range of 0.2-0.6 at a temperature of $800-1200{ }^{\circ} \mathrm{C}$ and with the applied strain rate $(\dot{\varepsilon})$ amounting to about $1 \mathrm{~s}^{-1}$. The samples were austenitized for $360 \mathrm{~s}$ at $1200{ }^{\circ} \mathrm{C}$. After the compression test, the samples were immediately cooled down in water so that their microstructure could be analyzed. Etching with a saturated picric-acid solution (Mi7Fe) was used, at a temperature of $70{ }^{\circ} \mathrm{C}$, to reveal prior austenite grains. Metallographic tests were carried out on an OLYMPUS GX 71 (Japan) optical microscope as well as on an electron microscope of the S/TEM/Titan (FEI) type, within a range of $245-300 \mathrm{kV}$ and with a resolution of the image of less than $0.10 \mu \mathrm{m}$. Foils were mechanically thinned and ionically polished in a PIPS (GATAN) device.

\section{RESULTS AND DISCUSSION}

\subsection{Analysis of the flow curves and the kinetics of recrystallization}

The $\sigma-\varepsilon$ flow curves of the investigated steel, obtained with the hot-compression tests, permitted us to determine the influence of the conditions of plastic deformation upon the strain hardening and the recrystallization of deformed austenite. The steel deformed to $\varepsilon=1.2$ displays flow curves varying in their shape, depending generally on the temperature and the strain rate (Figure 1). The flow curves recorded at the deformation temperature of $1200{ }^{\circ} \mathrm{C}$ show a distinct maximum of flow stresses for the minimum strain rate and a less obvious maximum of these stresses for the maximum strain rate (Figure 1a). However, the curves obtained in the $\dot{\varepsilon}$ test range clearly show that dynamic recrystallization processes occur under these compression conditions, whereas at a lower strain temperature $\left(900{ }^{\circ} \mathrm{C}\right)$, flow curves in the same range of $\dot{\varepsilon}$ indicate unambiguously that only dynamic recovery occurs under these compression conditions (Figure 1b).

The curves of the relaxation of stresses of the investigated steel in the range of the compression temperature $\left(800-1200{ }^{\circ} \mathrm{C}\right)$ generally display three distinct states of softening (Figure 2). The share of the first and the third
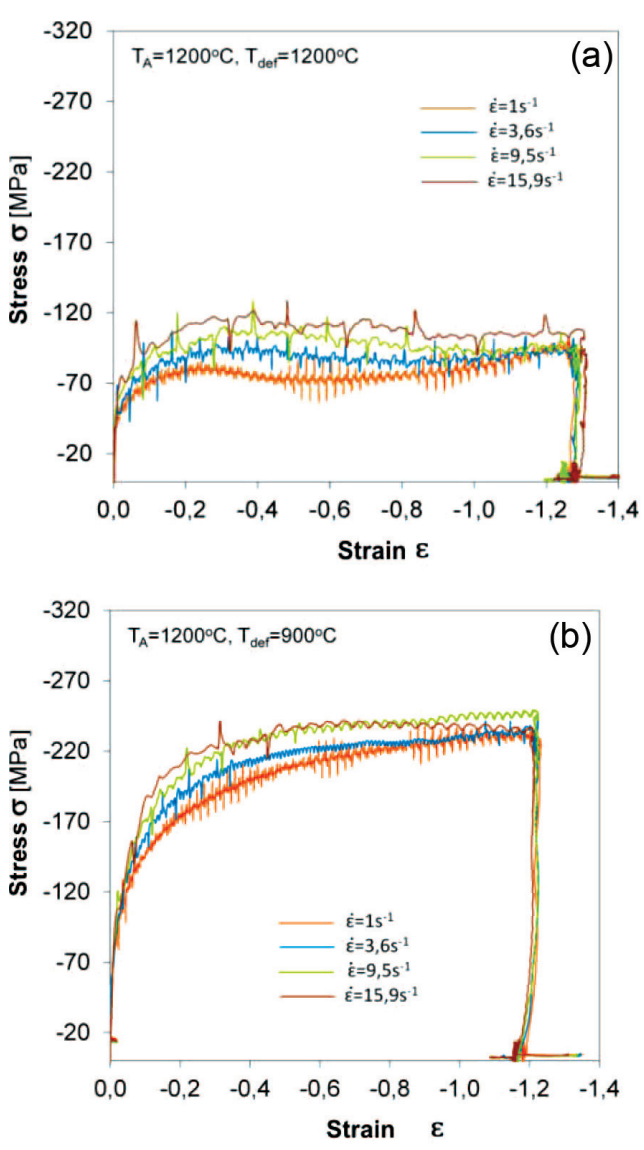

Figure 1: Effect of deformation temperature and strain rate of the compression test on the flow curves of the investigated steel austenitized at $1200{ }^{\circ} \mathrm{C}$

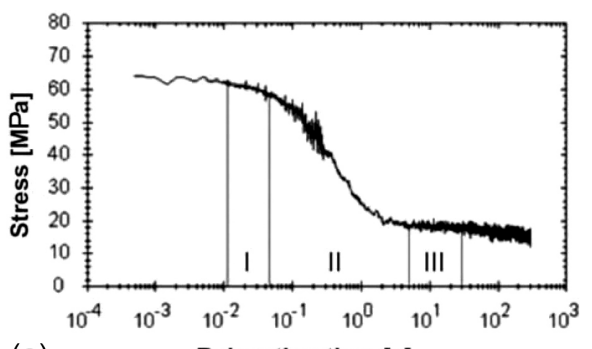

(a)

(a) Relaxation time [s]
\begin{tabular}{|c|c|c|c|}
\hline$\sigma_{\text {o1 }}$ & $\alpha_{1}$ & $\sigma_{\text {oIII }}$ & $\alpha_{\text {III }}$ \\
\hline 51.0169 & -5.6783 & 19.2885 & -1.1200 \\
\hline
\end{tabular}

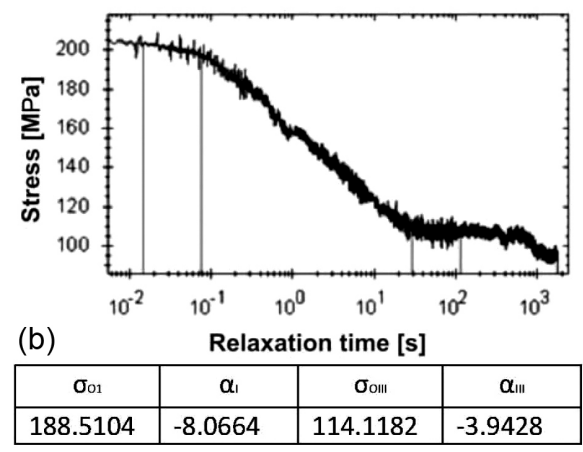

Figure 2: Curves of the stress relaxation of C-Mn-Nb steel, recorded in the hot-compression test and the method of determining the coefficients of linear equations of the stages of softening (I-III): a) $T_{\text {def }}=1200{ }^{\circ} \mathrm{C}, \varepsilon=0.14, \dot{\varepsilon}=1 \mathrm{~s}^{-1}$; b) $T_{\text {def }}=800{ }^{\circ} \mathrm{C}, \varepsilon=0.2, \dot{\varepsilon}=1 \mathrm{~s}^{-1}$ 
state in the drop of stresses is linear and occurs in the case of a steady and relatively low change rate of the stresses. This can be described with the logarithmic dependence in Equation (1):

$$
\sigma=\sigma_{\mathrm{o}}-\alpha \log \tau
$$

where : $\sigma$ - actual stress, $\tau-$ time of relaxation, $\sigma_{0}, \alpha-$ constants.

In the second state of softening, however, a violent drop in the level of stresses was observed. The responding values of the coefficients in Equation (1) determined for the analyzed stress relaxation curves were tabulated in Figure 2. It was found that in the case of the investigated conditions of the compression test, the coefficient of the inclination of the straight line $(\alpha)$ in the third state of stress relaxation is distinctly lower than for the first state and that the $\sigma_{\mathrm{o}}$ values increase with the reducing temperature of deformation. It may be suggested that this depends essentially on the coefficients of the inclination of stress relaxation versus the level of stresses. One should think that the slope of the straight lines of relaxation is a function of the material state, resulting from the course of the static or metadynamic recovery process, or a process similar to the creep of the material rather than - as it was suggested previously ${ }^{11}$ - a result of the machining effect of the Gleeble 3800 device.

The intensive drop in the level of stresses between the first and the third state of the stress relaxation is caused mainly by the process of static recrystallization or metadynamic recrystallization. The respective curves of the kinetics of these processes were determined analytically based on dependence (Equation (2)), concerning
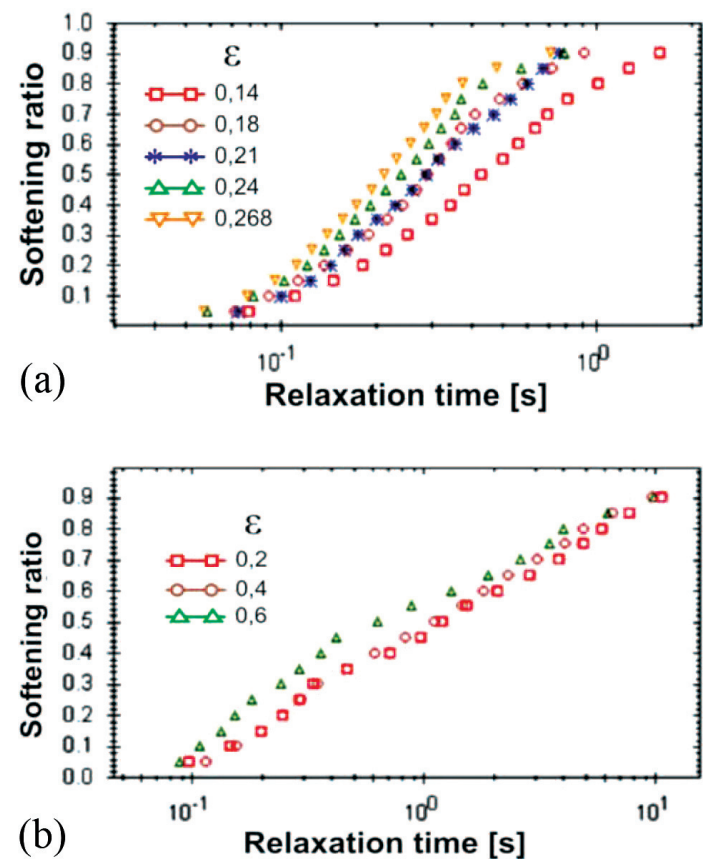

Figure 3: Influence of the degree of deformation on the process of isothermal softening of C-Mn-Nb steel after its austenitization at $1200{ }^{\circ} \mathrm{C}$ and compression tests at: a) $1200{ }^{\circ} \mathrm{C}$, b) $900{ }^{\circ} \mathrm{C}$, at the strain rate amounting to $1 \mathrm{~s}^{-1}$ the investigated HSLA steel, and they are plotted on Figure 3:

$$
\sigma=(1-x)\left(\sigma_{\text {o1 }}-\alpha_{\mathrm{I}} \log \tau\right)+x\left(\sigma_{\text {oIII }}-\alpha_{\text {III }} \log \tau\right)
$$

where: $x$ - the share of the recrystallized fraction after the time $\tau$ starting at the recrystallization, I, III - indices corresponding to the first and third state of the stress relaxation.

It was found that the sigmoidal course of the kinetic curves corresponds to the model exponential curve given by L. P. Karjalainen. ${ }^{12}$ It was also found that the isothermal holding of the investigated steel after its deformation in the range of $\varepsilon(0.14-0.27)$ at $1200{ }^{\circ} \mathrm{C}$ leads to the removal of the results of strain hardening caused by the static recovery and recrystallization (Figure 3a). At a lover temperature of deformation (about $900{ }^{\circ} \mathrm{C}$ ), besides these processes, a probable stage of metadynamic recrystallization was also revealed (Figure 3b).

\subsection{Metallographic analysis}

A metallographic analysis was performed with the determination of both the deformation-time-temperature-transformation (DTTT) diagram and the characteristic temperatures of phase transformations $\mathrm{AC}_{1}=710^{\circ} \mathrm{C}$
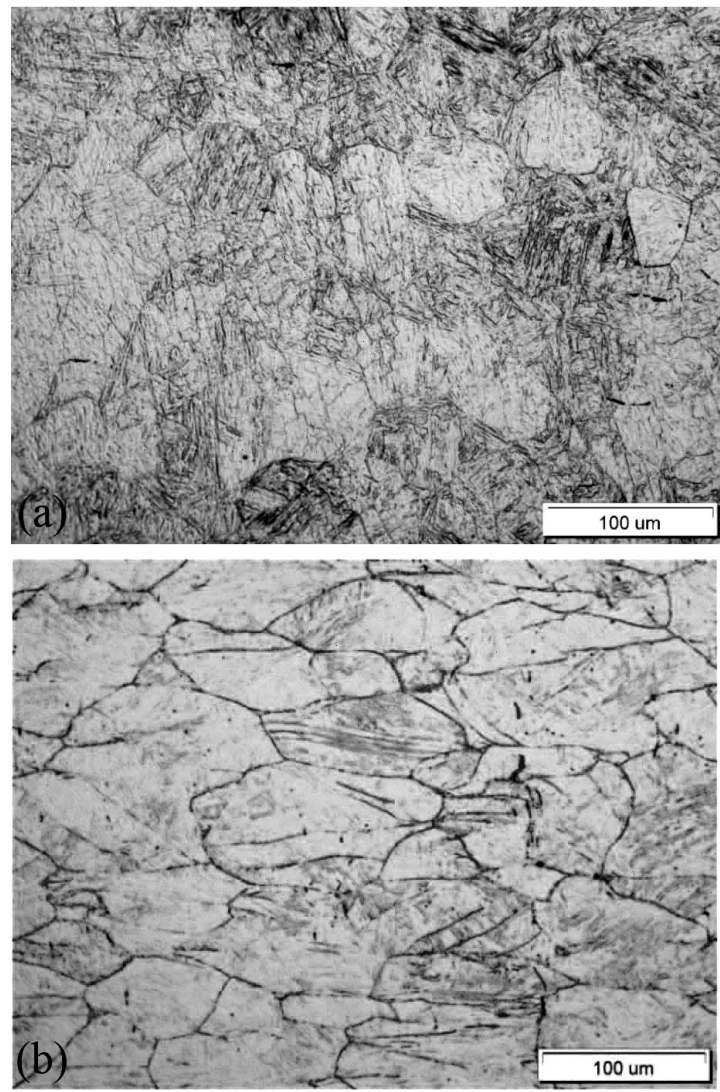

Figure 4: Influence of the degree and temperature of deformation of $\mathrm{C}-\mathrm{Mn}-\mathrm{Nb}$ steel on the structure of the initial grains of austenite: a) $\varepsilon=0.268, T_{\mathrm{def}}=1200{ }^{\circ} \mathrm{C}$, b) $\varepsilon=0.6, T_{\mathrm{def}}=900{ }^{\circ} \mathrm{C}\left(T_{\mathrm{A}}=1200{ }^{\circ} \mathrm{C}\right.$, $\dot{\varepsilon}=1 \mathrm{~s}^{-1}$ ) 


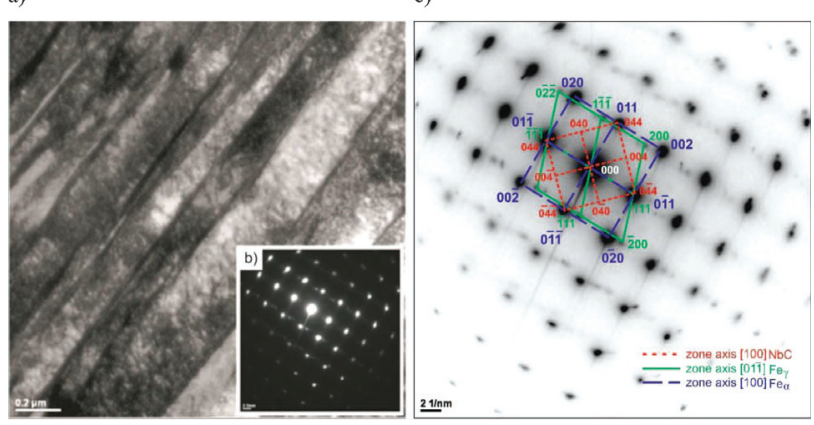

Figure 5: Microstructure of the lath martensite with residual austenite and precipitations of $\mathrm{NbC}$ : a) bright field, b) diffraction pattern, c) solution of diffraction pattern, C-Mn-Nb steel, $T_{\mathrm{A}}=1200{ }^{\circ} \mathrm{C}$, $T_{\text {def }}=1100{ }^{\circ} \mathrm{C}, \varepsilon=0.2, \dot{\varepsilon}=1 \mathrm{~s}^{-1}, \tau=30 \mathrm{~s} /$ water

and $\mathrm{AC}_{3}=809{ }^{\circ} \mathrm{C}$. The knowledge provided with this diagram allowed a detailed analysis of the phase transformations of the examined steel under hot compression, followed by cooling at a rate of approximately $70{ }^{\circ} \mathrm{C} / \mathrm{s}$ to about $30{ }^{\circ} \mathrm{C} / \mathrm{min}$. The martensitic transformation temperature was about $380{ }^{\circ} \mathrm{C}$, while the bainitic transformation temperature was about $530{ }^{\circ} \mathrm{C}$.

The results of the metallographic analysis of the investigated HSLA steel, hot deformed in the compression test, were gathered in microphotographs (Figures 4 and 5). It was found that the revealed shape and size of the austenite grains after the transformation $\gamma-\alpha$ ' depend mainly on the state of the deformed austenite structure and the course of thermally activated static processes. A significant influence on these processes is exerted mainly by the temperature and degree of deformation (Figure 4). The investigated steel compressed with a deformation $\varepsilon$ of about 0.27 at the temperature of
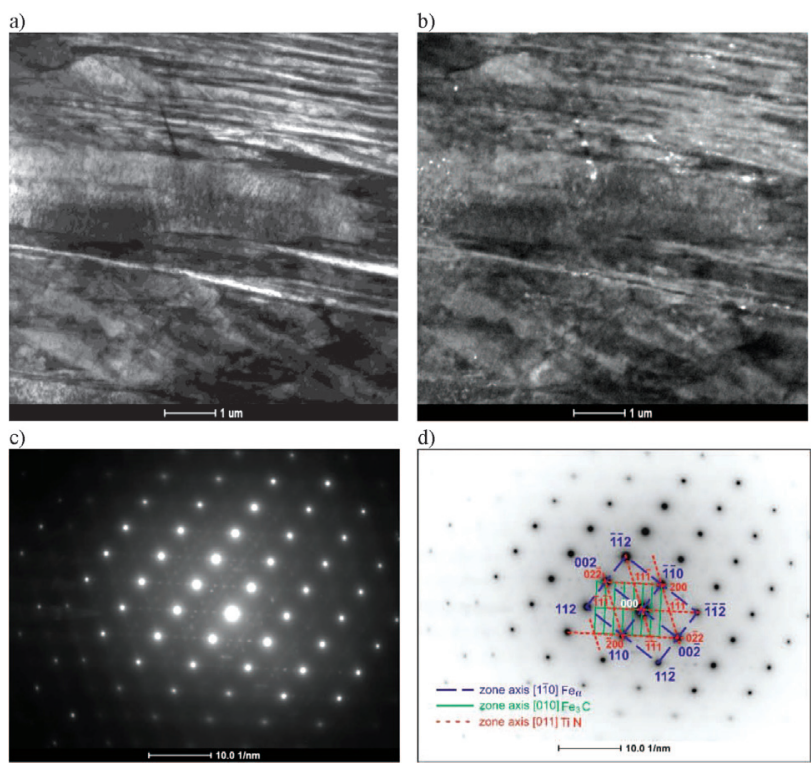

Figure 6: Microstructure of the lath martensite with TiN and Fe3C precipitations: a) bright field, b) dark field of (111) TiN plane, c) diffraction, d) diffraction solution, $\mathrm{C}-\mathrm{Mn}-\mathrm{Nb}$ steel, $T_{\mathrm{A}}=1200{ }^{\circ} \mathrm{C}$, $T_{\text {def }}=1100{ }^{\circ} \mathrm{C}, \dot{\varepsilon}=1 \mathrm{~s}^{-1}, \varepsilon=0.2, \tau=30 \mathrm{~s} /$ water
$1200{ }^{\circ} \mathrm{C}$, indicates dynamically recrystallized fine grains $\gamma$ in the matrix of primary austenite grains sized about $70 \mu \mathrm{m}$ (Figure 4a). In the case of a lower temperature of deformation $\left(800-900{ }^{\circ} \mathrm{C}\right.$ ) and when $\varepsilon$ is about $0.2-0.6$, the steel contains primary grains $\gamma$ in its structure, distinctly indicating merely the effects of strain hardening or dynamic recovery (Figure $4 b$ ).

TEM observations of the structures of thin foils also revealed a significant influence of the hot-compressiontest conditions and isothermal-holding time for the samples before the $\gamma$ - $\alpha$ ' transformation on the martensite morphology and the state of precipitations in the tested steel. This was identified after the steel had been cooled down from the temperature of deformation in the Gleeble device.

The resulting effects of the precipitation of intermetallic interstitial carbide and nitride phases - or probably carbonitride $\mathrm{Nb}$ and $\mathrm{Ti}$ phases - inherited in martensite, were generally identified with the technique of electron diffraction and the method of dark field.

The deformation of the investigated steel in the temperature range of $800-1200{ }^{\circ} \mathrm{C}$ and its isothermal holding after the deformation results in a varying degree of the formation of fine static precipitations of $\mathrm{NbC}$ and TiN sized about $60 \mathrm{~nm}$ in the matrix of the steel, which nucleate in the $\gamma$ phase and appear mainly at the boundaries and the lath of the $\alpha^{6}$ phase of a highly dense dislocation (Figures 5 and 6) as well as in the zones of twinned martensite. The images of diffractions also revealed reflexes $\mathrm{Fe}_{3} \mathrm{C}$, suggesting the possibility of a formation of bands of lower bainite in the course of cooling the HSLA steel (Figure 6). Similar effects of the phase identification for HSLA steels were also dealt with in the papers published by other authors. ${ }^{1,6,10}$

\section{CONCLUSIONS}

The results of the investigation concerning the $\mathrm{C}-\mathrm{Mn}-\mathrm{Nb}$ steel of the HSLA type lead to the following conclusions:

- Plastometric tests of the C-Mn-Nb HSLA steel performed on the Gleeble 3800 device, according to the method of hot compression and the relaxation of stresses in the temperature range of $800-1200{ }^{\circ} \mathrm{C}$, facilitate a successful analysis of dynamic recrystallization and the kinetics of recovery, static and metadynamic recrystallization.

- The microstructure of the investigated steel and the state of the precipitations of $\mathrm{Nb}$ and $\mathrm{Ti}$ carbonitrides, following the hot deformation, at a strain rate of about $1 \mathrm{~s}^{-1}$ within the temperature range of $800-1200{ }^{\circ} \mathrm{C}$, are mainly determined with the degree of deformation and the time of the relaxation of stresses.

- Hot deformation in the investigated range of temperature and strain rate ensures a refinement of the initial $\gamma$ grains of the investigated steel to about 
$40 \mu \mathrm{m}$, proportionally to the decrease in the temperature and increase in the degree of deformation.

- The decrease in the temperature deformation of the tested steel to about $800{ }^{\circ} \mathrm{C}$ and increase in the degree of deformation to about 0.6 impede the dynamic recrystallization and static removal of the consequences of strain hardening, not only as a the result of the recovery and static recrystallization, but also due to metadynamic recrystallization.

\section{REFERENCES}

${ }^{1}$ HSLA Steels 2011 - Proc. of the $6^{\text {th }}$ Inter. Conf. on HSLA Steels, Beijing, 2011

${ }^{2}$ Y. Weng, H. Dong, Y. Gan, Advances Steels, The recent scenario in steel science and technology, Part IV, Advanced HSLA Steels, Metall. Press and Springer-Verlag, Berlin, Heidelberg, 2011

${ }^{3}$ W. Ozgowicz, M. Opiela, A. Grajcar, E. Kalinowska-Ozgowicz, W. Krukiewicz, Metallurgical products of microalloy constructional steel, Journal of Achiev. in Mater. and Manuf. Eng., 44 (2011), 7-34

${ }^{4}$ J. Patel, B. Wilshire, The challenge to produce consistent mechanical properties in Nb-HSLA strip steels, Journal of Mater. Proc. Techn., 120 (2002), 316-321
${ }^{5}$ C. M. Sellars, From trial and error to computer modelling of thermomechanical processing, Ironmaking and Steelmaking, 38 (2011) 4, 250-257

${ }^{6} \mathrm{G}$. Purdy, Modeling recrystallization of microalloyed austenite: effect of coupling recovery, precipitation and recrystallization, Acta Mater., 50 (2002), 3075-3092

${ }^{7}$ S. Chao, K. Kang, J. J. Jonas, The Dynamic, Static and Metadynamic Recrystallization of a Nb-Microalloyed Steel, ISIJ Inter., 41 (2001), 63-69

${ }^{8}$ B. Dutta, E .J. Palmiere, Effect of Prestrain and Deformation Temperature on the Recrystallization Behavior of Steels Microalloyed with Niobium, Metall. and Mater. Trans. A, 34 (2003) 6, 1237-1247

${ }^{9}$ E. Kalinowska-Ozgowicz, Structural and mechanical factors of the strengthening and recrystallization of hot plastic deformation of steels with microadditives, Open Access Library, 20 (2013) 2, 1-246

${ }^{10}$ W. J. Liu, J. J. Jonas, Nucleation kinetics of carbonitrides in microalloyed austenite, Metall. Trans. A, 20 (1989) 4, 689-697

${ }^{11}$ L. P. Karjalainen, Stress relaxation method for investigation of softening kinetics in hot deformed steels, Mater. Sci. and Techn., 11 (1995), 557-565

${ }^{12}$ L. P. Karjalainen, J. Perttula, Characteristics of static and metadynamic recrystallization and strain accumulation in hot deformed austenite as revealed by the stress relaxation method, ISIJ Inter., 36 (1996) 6, 729-736 